\title{
On Nonlinear Vibration and Fretting Wear of Nuclear Fuel Rods Influenced by Coolant Cross-flow
}

Štěpán Dyk, Vladimír Zeman

NTIS - New Technologies for Information Society, Faculty of Applied Sciences, University of West Bohemia, Univerzitní 22, 30614 Plzeň, Czech republic. E-mail: sdyk@ntis.zcu.cz, zemanv@kme.zcu.cz

The paper deals with mathematical modelling of nuclear fuel rod (FR) vibration in TVSA-T fuel assembly induced by pressure pulsations of coolant. The FR is modelled as a system consisting of two subsystems - fuel rod cladding and fuel pellets stack - that can possibly impact-interact. Besides, the cladding subsystem can possibly loose contact with spacer grid cells that is another source of strong mechanical nonlinearities. The contact forces in all the contact points are represented by the force-velocity-displacement characteristics that include both normal and friction forces. The influence of coolant cross-flow is analysed using partitioned approach to fluid-structure interaction description. The qualitative change of FRs motion and the change of fretting wear of the FR cladding are shown.

Keywords: Fuel Rods, Vibration, Fretting Wear, Coolant Cross-flow

\section{Acknowledgement}

This publication was supported by the grant SGS-2016-038.

\section{References}

[1] BULÍN, R., HAJŽMAN, M. (2014). On the Modelling of Contact Forces in the Framework of Rigid Body dynamics. In Manufacturing Technology, Vol. 14, No. 2, pp. 136-141.

[2] CIESLAR, J., BROŽEK, M., BEDNÁ̌̌, B. (2013). An Experimental Assessment of Special Metal Castings in Reducing Abrasive Wear. In Manufacturing Technology, Vol. 13, No. 4, 423-428.

[3] HARRIS, C.M., PIERSOL, A.G. (2002). Harris'Shock and Vibration Handbook. McGraw-Hill, New York.

[4] HEIDLER, V., VIMMR, J., BUBLÍK, O. (2015). CFD Analysis of the Coolant Flow in Fuel Assembly of the VVER1000 Type Reactor. In: Proceedings of 21st International Conference Engineering Mechanics 2015 (J. Náprstek, C. Fischer (Ed.)), pp. 3 - 11, Institute of Theoretical and Applied Mechanics, Academy of Sciences of the Czech Republic, v.v.i, Prague.

[5] HÖNIG, V., MIHOLOVÁ, D., ORSÁK, M. (2014). Measurement of Wear Metals in Engine Oils by Atomic Absorption Spektrometry Method. In Manufacturing Technology, Vol. 14, No. 3, pp. 317-322.

[6] PELAGIĆ, Z., NÁGEĹ, M., ŽMINDÁK, M., RIECKY, D. (2015). Wear Simulation Modeling by Using the Finite Element Method. In Manufacturing Technology, Vol. 15, No. 2, 191-195.

[7] PEXA, M., ALEŠ, Z., PAVLŮ, J., ČEDÍK, J. (2015). Impact of Viscosity of Motor Oil on the Wear of Plain Bearings. In In Manufacturing Technology, Vol. 15, No. 4, 2015.

[8] ZEMAN, V., HLAVÁČ, Z. (2008). Dynamic response of VVER 1000 type reactor excited by pressure pulsations. In: Engineering Mechanics, Vol. 15, No. 6, pp. 2008. Association for Engineering Mechanics, Prague.

[9] ZEMAN, V., HLAVÁČ, Z. (2016). Mathematical modelling of friction-vibration interactions of nuclear fuel rods. In: Applied and Computational Mechanics, Vol. 10, No. 1, pp. 57-70. University of West Bohemia, Pilsen.

[10] ZEMAN, V., DYK, Š., HLAVÁČ, Z. (2016). Mathematical modelling of nonlinear vibration and fretting wear of the nuclear fuel rods. In Archive of Applied Mechanics, Vol. 86, 2016, pp. 657-668. 